Disponível em

http://www.anpad.org.br/rac

RAC, Rio de Janeiro, v. 16, n. 1, art. 2,

pp. 23-38, Jan./Fev. 2012

$(\mathrm{coc})$ EY-No

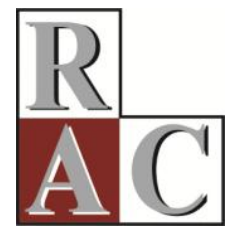

\title{
Building Social Capital for Internationalization
}

Suzana Braga Rodrigues *

E-mail: srodrigues@rsm.nl Universidade FUMEC, Rotterdam School of Management - Erasmus University Belo Horizonte, MG, Brasil.

John Child

E-mail: j.child@bham.ac.uk Birmingham Business School - University of Birmingham

Birmingham, Reino Unido.

* Endereço: Suzana Braga Rodrigues

Erasmus University, Burgemeester Oudlaan 50, 3062 PA Rotterdam, The Netherlands.

Copyright (C) 2012 RAC. Todos os direitos, até mesmo de tradução, são reservados. É permitido citar parte de artigos sem autorização prévia, desde que seja identificada a fonte. 


\title{
Resumo
}

Capital social pode ser definido como relacionamentos sociais que conferem benefícios atuais ou potenciais. Trata-se, portanto, de um tipo particular de recurso. As pesquisas recentes chamam atenção para a maneira como conexões e relacionamentos (networking), tanto domésticos quanto internacionais, podem ser crucialmente importantes para pequenas e médias empresas (PMEs) que buscam exportar ou Investir no exterior. Contudo pouco ainda se sabe sobre como as empresas iniciam, desenvolvem e mantêm o capital social. O presente artigo tem por base o estudo de 32 PMEs britânicas que exportam ou, tentam exportar, para o Brasil e de agências institucionais britânicas, cujo papel consiste em facilitar a condução de negócios entre as PMEs britânicas e brasileiras. O estudo abordou tanto as funções do capital social para as PMEs quanto o processo por meio do qual isso foi desenvolvido. A pesquisa apresentada neste trabalho confirma o valor do capital social no empreendedorismo internacional. O capital social pode facilitar a obtenção de informação e interpretação das oportunidades de mercado, além de outras vantagens. A pesquisa também confirma a importância vital da confiança interpessoal na sustentação do capital social entre pequenas empresas.

Palavras-chave: capital social; confiança; internacionalização; PMES; setor petróleo e gás.

\begin{abstract}
Social capital may be defined as social relationships that confer actual or potential benefits. It can therefore be understood as a particular type of resource. Recent research has drawn attention to how connections and relationships (networking) both at home and abroad can be crucially important for small and medium-sized enterprises (SMEs) seeking to export or invest abroad. However, relatively little is known about how SMEs initiate, develop and maintain network relationships. This paper reports a study of 32 British SMEs exporting, or attempting to export, to Brazil and of domestic institutional agencies whose role was to facilitate business conducted between British and Brazilian SMEs. The study explored both the functions of social capital for the SMEs and the process whereby it was developed. Its findings confirm the value of social capital in international entrepreneurship. It can provide information, interpretation, market opportunities, and some degree of protection against the risks associated with foreignness, newness and smallness. The study also confirms the vital importance of personal trust in sustaining social capital between small firms.
\end{abstract}

Key words: social capital; trust; internationalization; SMEs; oil and gas sector. 


\section{Introduction}

Internationalization has historically been associated with multinational corporations (MNCs). Recent trends suggest, however, that the international market is increasingly populated by small and medium-sized enterprises (SMEs) as well. With globalisation, many SMEs can no longer survive in sheltered domestic markets and others have been forced to follow their customers as they move into foreign markets in order to maintain their relative position in a supply chain network. SMEs are, however, relatively deficient in terms of having the resources required to support internationalization (Buckley, 1989; Fujita, 1998). Recent research has drawn attention to how connections and relationships (networking) both at home and abroad can be crucially important for SMEs seeking to export or invest abroad (R. I. D. Harris \& Li, 2005). Social capital is now viewed as crucial to offsetting the liabilities that SMEs face, and they are increasingly using it to overcome the problems of limited resources, experiences, and credibility ( $\mathrm{Lu} \&$ Beamish, 2001). These new insights have stimulated enquiry into social capital, which may be defined as social relationships that confer an actual or potential benefit. Nevertheless, the processes whereby SMEs develop social capital in the process of internationalization remain largely unexplored. The study reported here aims to fill this gap by investigating how British SMEs exporting to Brazil developed social capital to support their internationalization.

\section{Building Social Capital}

The role of social capital as an asset that is deployed in the process of creation of new ventures has been discussed quite extensively (Ferrary \& Granovetter, 2009; Johanson \& Vahlne, 2003; Oviatt $\&$ McDougall, 2005). The theory of social capital suggests that firms create, and are embedded in, a web of relationships which may offer access to resources and opportunities of different natures. Different meanings have been attached to social capital. Some researchers view it in terms of resources which may be available to the firm through participation in networks (Coleman, 1988; Nahapiet \& Goshal, 1998), while others conceive it in terms of the unique characteristics that define loosely connected social structures (Bourdieu, 1980; Coleman, 1988; Putnam, 1993).

Although the literature on social capital cannot be classified into neat categories, the various meanings attached to the concept, both as an asset and as a set of social relationships, nevertheless extend our understanding. Thus, it is useful to distinguish those views which define social capital as an asset that is instrumental to the achievement of individual or organizational goals (Freeman, 1999; Stuart, 1999; Uzzi \& Gillespie, 1999) from those that define social capital in terms of the quality of relationships which constitute network membership (Burt, 1997; Tsai \& Ghoshal, 1998). Basically, the rational perspective emphasizes the instrumental dimension of social capital, while the social behavioural view focuses on the dynamics of social ties.

The instrumental view suggests that social capital is a property of individuals or social groups and that engagement with networks may accrue benefits which otherwise would not be available to the firm (Nahapiet \& Goshal, 1998). The instrumental view has its origins in Coleman's (1988) insights that relationships could mediate access to resources. His theory presumes that organizational actors intentionally mobilize relationships to facilitate or advance their interests. From a purely instrumental point of view, a network would primarily offer key connections that could mediate an actor's interests, such as access to gatekeepers or key actors who are strategically positioned in circuits of power. Such actors are considered as social capital insofar as they represent promises or expectations about access to information, knowledge, financial resources or political contacts which are valuable to the firm. The rational view essentially reinforces the point that firms aim to initiate and cultivate social ties selectively, in accordance with the utility attached to a particular relationship. 
Within the rational perspective, resource analysis suggests that the capacity of actors to mobilize relationships for their own benefit and that of third parties is central to competitive advantage. Research at firm level has suggested that social capital can expand the firm's connectivity - the number of ties and the scope of these ties - across lateral and vertical boundaries, and is essential mainly for small firms seeking to enter and operate in foreign markets (Baker, 1990). Thus, firms may belong to different types of networks which are more or less independent or which could also overlap in their specialties. According to this perspective, firms are able to buy social capital (Boisot, 1988) through purchasing introduction and access to potential customers, key actors and informational institutions that can grant licenses. Relevant networks for SMEs include agents, distributors, suppliers, professional and industry associations, and customers, such as multinational corporations.

Rather than emphasizing the intentionality of actors, the social behavioural view suggests that motivation alone is not enough to obtain access, since social capital is embedded in social and political contexts (Granovetter \& Swedberg, 1992), for which access is limited to those who fit into, and share views and key characteristics with existing members of, such networks. There is a clan aspect to networks (Boisot \& Child, 1996), which regulates inclusion and exclusion of membership.

Exponents of this theory suggest that social capital is regulated through behavioural norms, shared values, trust, commitment, relations of reciprocity, reputation and mutual recognition (Bourdieu, 1986; Coleman, 1991; Putnam, 1993). Relationships may therefore open opportunities to smaller and less powerful actors. SMEs, for example, may not have direct access to an MNC's customers, but might access them through their attachment to other actors in the supply chain (Axelsson \& Easton, 1992). In Coleman`s view, social capital dynamics involve the creation of expectations and mutual obligations among actors (Coleman, 1988). Above all, social capital is fertilized through trust and reciprocity. Its dynamics develop around members' goodwill to repay favours, and through sanctions for failing to do so (Biggart \& Delbridge, 2004).

\section{Social Capital and Its Relevance to Internationalization}

Though there are several sources indicating how social capital can trigger and foster internationalization (Johanson \& Mattsson, 1988), not much is known about how SMEs develop and maintain network relationships. The literature suggests that SMEs engage in several types of networks, each with different degrees of involvement (Seifert, Child, \& Rodrigues, 2011). It is evident that most SMEs are able to reach international markets only through the help of third parties, which vary from individual agents to institutions that provide formal support for export activities. In the UK these may involve the governmental UK Trade and Investment (UKTI), chambers of commerce, and industry associations. One common way in which SMEs may access foreign markets is through piggy-backing on MNCs (Child \& Rodrigues, 2008). This is more frequent in customer-supplier conditions where SMEs have to follow the geographical movement of MNCs in order to survive. Obtaining security of sales through membership in the supply-chains of large players can be a big premium for SMEs, but it also creates the risk of becoming highly dependent.

Building ties with large players can be very important to reduce costs, to adjust for asymmetry of information, and to cope with the other liabilities SMEs face in international environments. If the SME is already an experienced exporter, it might as well draw from already known and established sources. It could for example use its connections with MNCs in other countries to access a yet unfamiliar market, or alternatively use one of its own sales agents. SMEs may find out that the less costly and risk adverse strategy to assess a new market is through an indirect route, using relationships it already has with partners and agents elsewhere, or through joining a consortium as a means of risk sharing.

Despite the fact that some SMEs may be very experienced players, they may still suffer from liability of newness when entering into an unfamiliar market. Liability of newness- being a new 
exporter or new to the market- exposes SMEs to 'embedded risks' in foreign countries. Such risks are usually not described in reports and are difficult to figure out. Local players may not perceive them as risks since they have already developed means to anticipate their presence and efficient ways of dealing with them. Lack of knowledge of embedded risk puts a foreign SME at a disadvantage vis-àvis their local competitors. Two sources of social capital may be important in these situations: personal relationships and institutional support. Locals may be very important mediators for foreign firms concerning informal norms dealing with economic transactions. For example, not only can they introduce the firm to key relationships but they also may know which third agents are trustworthy, and more easily detect signs of opportunism. They may also have in-depth knowledge of short-cuts to bureaucratic problems. These considerations point to the various functions that social capital can perform for internationalizing SMEs.

We now illustrate the functions of social capital for internationalizing SMEs and the different phases that SMEs may go through in their attempt to build social capital for internationalization initiation, development and maturity. The illustrations derive from a study of British firms exporting to Brazil.

\section{Scope and Method}

This study accessed the views and reported experiences of leading executives in British SMEs exporting to Brazil. Brazil is a potentially attractive foreign market, as one of the four large emerging economies in the world. It is, however, a country in which one would expect foreign entrepreneurs to experience considerable difficulty, and where they would therefore need to rely heavily on social capital both domestically and in Brazil. The psychic distance between Brazil and the UK is high due to the mutually low familiarity with each country's language and culture, and the bureaucratic complexities of the Brazilian regulatory system (Child, Rodrigues, \& Frynas, 2009). The liability of foreignness in Brazil is also high. Bureaucratic restrictions are largely responsible for the fact that Brazil is a relatively costly country into which to export goods (World Bank, 2010) and the situation is often complicated by official corruption (Transparency International, 2008).

The study included 32 British SMEs exporting, or attempting to export, to Brazil. As the nature of the study was exploratory, we conducted personal interviews with 37 entrepreneurs from these SMEs. These were the individuals most closely involved with their Brazil business ventures. We use the term entrepreneur to describe the senior SME personnel interviewed, because a majority of them were part, or sometimes sole, owners of their companies. All were decision-makers concerning their firms' business with Brazil. In addition, twenty-three persons from institutional agencies were interviewed concerning their role in facilitating British SME business with Brazil. Most of these agencies were located in the UK, since we were interested in local/national agencies in their role of facilitating business with Brazil, but we also interviewed key actors in Brazil, whose role included facilitating business with the UK. Table 1 indicates the institutions and main professional positions of the institutional actors interviewed in both countries.

Table 1

Agencies and Individuals Interviewed in Brazil and the UK

\begin{tabular}{l}
\hline Agencies and Individuals Interviewed in the UK \\
\hline Director General, Canning House \\
Director: Europe \& Americas, UKTI \\
Brazil Desk, UKTI \\
\hline
\end{tabular}




\section{Table 1 (continued)}

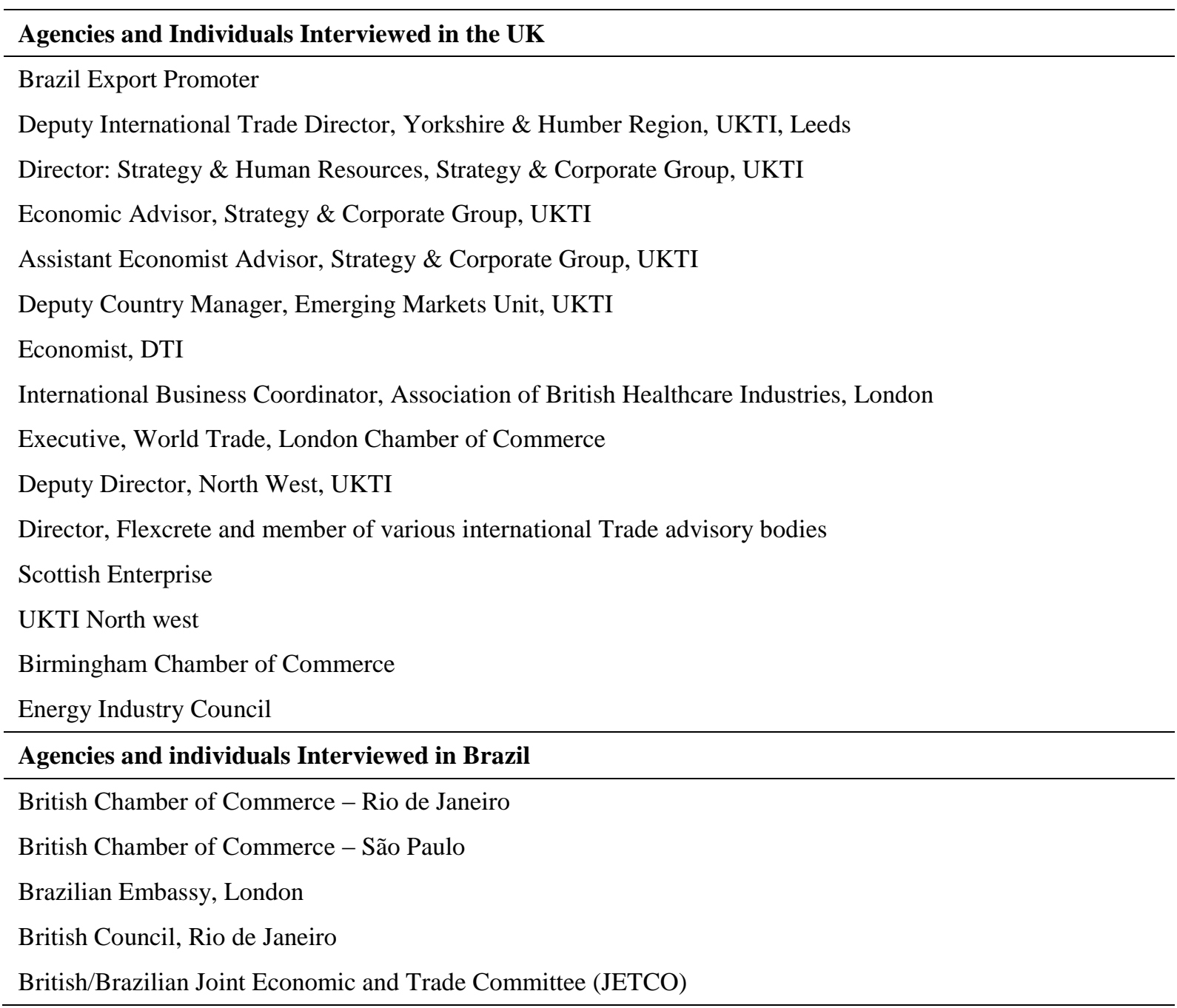

All the interviews were tape recorded. After establishing the history and profile of each firm, questions were asked about the firm's internationalization strategy, how its business with Brazil was established and about any relationships involved, perceived psychic distance between the UK and Brazil, difficulties experienced in doing business with Brazil, and the role of social capital in facilitating the firm's entry to and operation in Brazil.

\section{Functions of Social Capital}

Most of the SME entrepreneurs reckoned that relationships with key actors, such as agents, customers and institutions at home and abroad helped them to avoid incurring unnecessary costs. The majority claimed that they could not afford to maintain an office in Brazil and also pay expatriates' salaries. In contrast with MNCs, most firms did not have an appropriate structure to make the best use of expatriates, since their staff did not have previous managerial experience abroad. Having an agent or representative abroad helped to avoid the costs of lack of information about the culture and institutions.

Social capital also had the function of overcoming liability of newness. Institutions were helpful for beginners; those who had little information about Brazil. Institutions nevertheless were of little help for those companies with very specialized products or services. Some companies, in particular 
those providing specialized engineering, did not have much information about the competition, customers` needs, requirements about local standards, and the level of market development. For those companies whose markets were very specialized, export promotion institutions could offer little assistance towards creating or expanding their customer basis in Brazil.

Since most of the firms affirmed that they knew little about Brazil and its business environment, finding the appropriate partners, agent or representatives was also crucial. Building a trustful relationship with them became essential to avoid various types of risk: institutional, financial and agency (Child \& Rodrigues, 2004). Finding a partner or agent was also important to obtain information about the market. Regarding this aspect, only specialized agents/representatives were able to help. Many companies also had to rely heavily on partners and agents to make sense of legislation and tax systems. The partners or agents were also useful in dealing with sensitive matters that the SMEs wanted to avoid, such as bribery and other ethical issues.

\section{Phases in Building Social Capital}

Building social capital in unknown markets may not be an easy task, even for experienced players. Figure 1 suggests the different phases that SMEs may go through in their attempt to build social capital for internationalization; namely initiation, development and maturity.

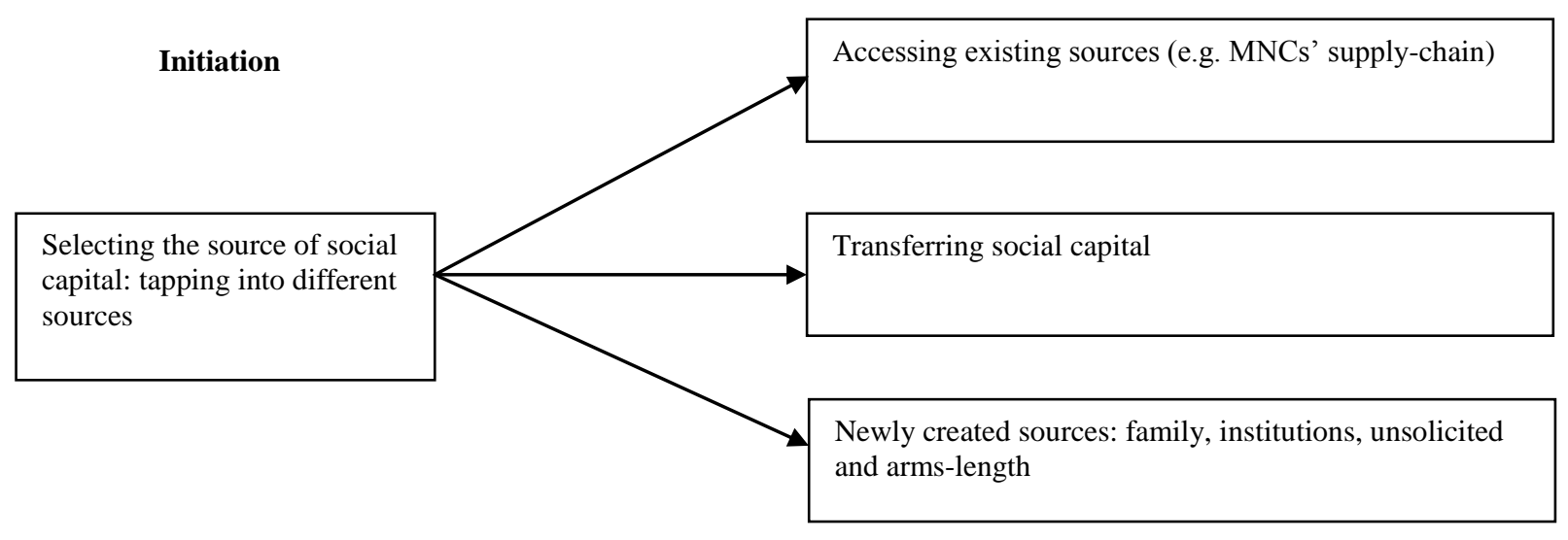

Development

Experimentation, trial and error, learning by doing

Adapting to each other: finding areas of collaboration, developing commitment and common interest

Withdrawing from the market

\section{Maturity}

Nurturing social capital: trust and reciprocity
Learning more about the partner/agent

Managing through informal governance mechanisms

Figure 1. Internationalization through the Process of Creating and Developing Social Capital. 


\section{Initiation}

SMEs have little influence within their environments and few resources with which to develop such influence. As a result, they have to adjust to environmental uncertainties without being able to reduce them to any significant extent. They therefore have to rely heavily on external parties to help them deal with the uncertainties. They often attempt to enhance their ability to cope with a complex environment through collective organization among themselves and/or by seeking help from trusted partners with close knowledge of the environment in question (Child et al., 2009). In the case of internationalizing SMEs, the partners they seek out in their domestic environment can include export promotion agencies and other members of export clubs. In the foreign environment they can include agents, distributors and local equity-sharing partners. SMEs are looking to secure both information and protection through developing trust-based relationships within these networks.

There were three modes by which the SME entrepreneurs studied initiated the creation of social capital relevant to doing business with Brazil. The first mode was through accessing existing sources of social capital. The second involved transferring social capital from previous business relationships, and the third mode was through creating new relationships.

\section{Accessing Existing Sources}

Most of the firms were already experienced exporters. The firms' proportion of total sales value arising outside the UK averaged 61.7 percent, and under one-third of them relied on the domestic market for more than 50 percent of their sales. However, on the whole, they have not had a long engagement with Brazil, with an average of only 4.6 years since their first contact with Brazil. So far as Brazil was concerned, most were early starters in Johanson and Mattsson`s (1988) terms, which meant they needed to learn a lot on their own account. The extension of their internationalization to Brazil benefitted from two main existing sources of social capital: membership in operational networks and connections to domestic institutional agencies.

Many of the firms studied were already members of an international supply chain which linked them with the Brazilian market through agents and contractors. For example, the SMEs operating in the oil and gas sector were already members of existing international production networks. They had initially accessed the Brazilian market through American contractors before they set up an operational office in Brazil. The founder and CEO of a marine engineering firm commented that:

"Once you're in the offshore business you can't survive and be international without Houston. So, you know, for lots of the clients with major projects really the concept is from Houston, so you have to have a Houston office, otherwise you're not real in the business".

However, SMEs do not tap into their social capital only for accessing new markets, but also to secure operational support. In some cases, a small business cannot meet an unexpected order, so it has to contract work out to other companies. Contractors which are licensed to provide services in other countries constitute an import source of social capital for international expansion because they have the flexibility to hire local labour, as well as knowledge of local financial procedures and tax rules. Sometimes, they provide a means to circumvent the restrictions imposed by such rules. For example:

"Petrobras of course have never paid us from Brazil because you have to be registered as a company in Brazil for that. So they paid us via a drilling contractor, you know, that we've been doing the work for. They just put a variation on his contract so that the drilling contractor can pay us outside the country and I've no problem with the taxes and retention and all the rest of it".

Many British SMEs have already established relations with institutional agencies that are involved in assisting smaller firms enter new foreign markets. These include regional development 
agencies, chambers of commerce, industry associations, international business councils and cultural organizations. In the case of Brazil, financial support for this activity is available from the central government (UK Trade and Investment) and local support is provided by British consulates. Membership in these agencies itself constitutes a form of social capital that can provide basic information on new markets; which some respondents found to be valuable at a stage when they had no knowledge about Brazil. In addition, the agencies can help initiate the development of other social capital for SMEs by subsidizing trade missions abroad, and making personal introductions. The personal introductions are to potential partners in Brazil and also to other British firms with relevant experience of doing business with Brazil. S. Harris and Wheeler (2005) reviewed the importance of inter-personal relationships in SME internationalization and found that many such relationships are formed in the home country prior to entry into new overseas markets.

All but five of the companies studied had received some export-related assistance from one or more institutional agencies. Seventeen, or just over half, of the companies had joined a trade mission to Brazil sponsored by one of the above agencies. Twelve had received assistance in establishing business or social contacts in Brazil; generally through a UK consulate or chamber of commerce in Brazil. A few had also been helped in finding interpreters for visits to prospective customers or local agents; an important requirement for building social capital in business relations between two countries where the mutual knowledge of each other's languages is quite limited.

Companies which had a positive view of institutional agencies were generally those with no or little prior knowledge of Brazil and no prior contacts in Brazil. Such companies benefited greatly from assistance in their first steps in Brazil, including establishing contacts with relevant Brazilian firms through trade missions, and attending social events sponsored by local consulates. By contrast, companies that had already established some social capital in Brazil - for example those that had a local partner - tended not to rate institutional services highly.

\section{Transferring Social Capital from Previous Business Relationships}

Some entrepreneurs had transferred social capital relevant to business with Brazil from their previous employment in a larger international company. This involved migrating already established business relations to their new ventures. The social capital provided by the transfer of already longterm relationships was particularly valuable because it was mature. It rested on a tried-and-tested combination of inter-personal trust and competence in honouring commitments. For this reason, it could provide business opportunities in a new foreign market very quickly. For instance, a company offering consulting services on supply-chain management had been established two years prior to this study by two entrepreneurs. One of The entrepreneurs brought many contacts with major customers, such as supermarkets, with him from his previous employment. This served as a foundation for the new business. Through these relationships, the company immediately achieved exports worth 50 percent of its business, with 10 percent going to Brazil. Another small company manufacturing filtration materials was founded by two owner-entrepreneurs when it was spun-off from the large paper-making group they had worked for. They took an established international customer list with them, and exports accounted for 85 percent of total sales at the time of this study.

\section{Creating New Relationships}

When institutional agencies or previous contacts were involved with the building of social capital for SME entrepreneurs, the latter were normally already aware of the market potential that Brazil offered. Either the agencies had publicised this potential through their export promotion activities, or the firms had approached the agencies to take advantage of their (often subsidised) 
market intelligence services. So they sought new social capital as a means of implementing a business development opportunity that they had previously identified and even researched. Social capital was applied in a rational way to the fulfilment of strategic goals.

Trade missions travelling abroad typically include social events at which SMEs can make new connections with potential agents and customers in new markets. As already noted, these new connections tended to be regarded as particularly valuable by the members of firms that had no previous contacts with Brazil. However, they could also strengthen existing ties. For example, the chairman and sales director of one company commented:

\begin{abstract}
"When you go out there by yourself you feel you are in a strange country, you are an individual ... going to a party, then you can share support one for another, you know you have the help from the embassy; so getting to know the officials there you know that you can call upon their services if necessary. You know that there's a great wealth of information there, and also the receptions we had there in the evenings have been used from the point of view of inviting my agent, plus his customers; that gives some degree of support and verification as to who we are. It elevates our own company. So it is worthwhile".
\end{abstract}

For approximately one-third of the companies, business with Brazil was triggered through serendipity in the sense of fortunate, chance events. These events generated new social capital but in a way that was not planned or even, in the beginning, sought after. They included unanticipated contact from Brazilian business people seeking to do business, suggestions from their major international customers, and chance meetings. Although unplanned, such events generated an awareness of the possibilities for exporting to Brazil. An example of a productive, chance meeting was given by the director of a floor coating company:

"I actually thought about Brazil as a market after I listened to a Brazilian embassy minister, whom I met at a dinner, and she talked about her market and she asked me if we were doing anything in Brazil. I had to confess to her 'no', but having listened to what she said we were going to get on and do it, and I did".

Significantly, serendipitous encounters could lay the basis for a trust-based personal relationship to support business in a new market. For example, one company making materials for electrocoatings was approached by a Brazilian business man who sought to represent the company in Brazil and who subsequently became its sole trusted distributor there. Brazil now accounts for 10 percent of the company's total export sales value. Its technical director described the ensuing relationship with his Brazilian distributor as a 'socio-commercial sort of relationship with the distributor and his wife'. There is no legal contract involved - transactions are based purely on social capital.

\title{
Development
}

This last quotation provides a clue as to the main way in which social capital with Brazilian partners, once established, was developed by the British entrepreneurs engaged in business there. This was through the establishment and deepening of personal trust-based relations. These relations often broadened to include the actors' families, with home invitations and even joint holidays being involved. The highly sociable culture of Brazil doubtless played a role in encouraging this pattern of behaviour, perhaps more so than is likely in many other countries. The executives interviewed frequently noted how the open and sociable culture of Brazil leads to business advantage deriving from socializing more than in many other countries they had experienced. Brazilians, they described, like to throw parties at which existing and potential customers may be present. They are also happy to take their British partners to pay social calls on business associates and these can also provide new marketing opportunities.

Most of the SMEs and their Brazilian partners were firms run by their owners. It appears that the personal confidence that resulted constitutes a valuable support to social capital. Many instances were cited of how the fact that the British company and/or its Brazilian agent or partner was a 
personally-managed or family business engendered a special kind of confidence that came from personal commitment and even honour. This is because owner/entrepreneurs are accountable to themselves rather than to shareholders, which lends their commitments a personal integrity and legitimacy. By contrast, a manager from a large company is seen to be representing superiors who may not have this personal commitment and who could therefore fail to support the spirit, if not the letter, of an agreement. While competence, regarding the ability to deliver on promises both to supply and to be paid, is essential in business transactions and was fundamental for entrepreneurial success, it was social capital that provided the confidence to enter into those transactions in the first place.

The importance of being able to develop and maintain adequate social capital in a 'difficult' regulatory environment like Brazil's was highlighted by the cases of failure. Four of the SMEs studied were withdrawing from doing business with Brazil. All four companies were in the oil and gas sector in which a particularly dense set of regulations and quasi-official relationships have to be penetrated in order to gain business. In each case, the SMEs were unable to find a reliable local employee or agent through whom they could access or create the network they required. There was little doubt about the technical competencies of the four companies that experienced difficulties in Brazil. Possibly through bad luck, but just as likely through poor selection or an unfortunate handling of the relationship, they had failed to gain the support and trust of local partners or staff. The result was that their partners were poorly motivated at best and opportunistic at worst. For example:

\footnotetext{
"when we see signs that are out of the character that you want, you hope that it's an aberration, when actually you should take action straight away. I mean as soon as he wanted a BMW as a company car I should have fired him. Right? Because when you just start, you can't do that - you're looking for the minimum solution. When the profits are there and it's all going well, well if he wants a BMW, what the hell, you know. But when you start ... So you have to be more ruthless. More careful with selection and then more ruthless. Once you see things that are out of the model that you have, you must take action".
}

In another case, the company discovered that its local Brazilian partner was trying to take business away from it. The managing director of one company regretted that he had not spent more time finding the right local staff in Brazil and winning their trust. In these cases of failure, the level of social capital that the firms acquired was not reliable or adequate to cope with the liability of foreignness, and they generally ended up withdrawing from Brazil.

Failures of social capital recall that a degree of experimentation may take place as it is developed. Sometimes new collaborators and partners have to be found because of failures. In other instances, new areas of collaboration open up over time. The broadening of joint activities can develop mutual commitment and hence deepen the relationship; while the same strengthening of mutual confidence provides the foundation for widening the business, given the attendant risks of so doing. For example, the joint managing director of a consultancy company, describing how he had built his network for Brazil, said:

\footnotetext{
"So it's a question of having a network, and you build it ... I am just wondering how many key people we've got... in total, we've got 12 entities, either an individual or a group of people in an organization, who collectively would help us develop the Brazil business. Each of these hangs on a network of people...to make a UK-Brazil business work, you've got a number of key contacts, 12 to 15 I would suggest, probably in both countries".
}

\section{Maturity}

Maturity denotes a stage in the evolution of social capital at which it has attained a stable, sound and steady state, in the context of internationalization to a given foreign country. At this stage, the social capital of the SME has matured in the sense of incorporating a high level of interpersonal trust sufficient to provide complete confidence in the intentions and capabilities of their foreign business partners, so that reliance on legal contracts, controls and monitoring becomes minimal. Perhaps the 
most significant indicator of maturity in the firm's social capital is its willingness and that of its partners to provide mutual support, if necessary, beyond the scope of their normal transactions.

Because most of the SMEs studied had not engaged with Brazil for very long, few of them had achieved maturity in the evolution of their relevant social capital. For those firms that had achieved some maturity, the support provided through their relationship with local partners in Brazil had superseded that coming from domestic sources, such as chambers of commerce. The quality of their relationship with local partners had matured to the point at which it went well beyond initial expectations. One manifestation of this lay in the development of a strong mutual identity which overcame the psychological liability of foreignness. This, in turn, could enhance the SME's standing with local customers and help to generate contacts with new ones. One CEO, talking about his Brazilian partner, said:

"I've been to the home, and shared food with them... he shields me from a lot of the individual problems on the shop floor, or cultural problems. When you get there, I'll go into the field with him, there aren't real problems, and it's like talking to you: they're Brazilian, you're Brazilian and ... excellent relationship".

\title{
While another SME director said of his Brazilian agent:
}

"We have become friendly with these people, you know, simply because it could be useful to one another, but, you know, it's still seeing their family and everything. And then there'll be a lot of social activities. Brazilians like to party, you know, so off they go. So, you know, we enjoy that as well. Then there'll be new customers or potential customers that they like to sort of trail you round... we just sit in the back of the car and sort of turn up in places".

A further indicator that social capital has matured arises when the partners can depend on each other to offer assistance in dealing with crises or major problems that fall outside the normal scope of their business transactions. This again is an instance where the depth and value of the relationship transcends initial expectations. A marketing manager made the point this way:

\begin{abstract}
"If you can build a relationship on trust I think, for anything in life, then obviously that relationship will be long lasting; and we always find when we do hit difficult times and we do have situations where competitors target our business, then our agents will put up a fight and do it in the correct way because ... You know, some people would probably walk away, but they don't because we back them up and we'll support them".
\end{abstract}

And the managing director of a consulting firm said:

"Some of them I trust completely. Mario is one of them; there are one or two others where you can say 'look I've got a problem', and they won't take advantage of it. In the same way they can come to you and say - I remember one of them saying to me I the middle of a project - 'I am stuck'. And then you sit down and you help them through their problem, but they appreciate that".

As noted already, entrepreneurially-led SMEs more readily do not distinguish between interpersonal trust and inter-organizational trust because their leading executive can be identified with the firm. One managing director commented that this identity between personal and business roles in the same relationship with overseas partners can be both strength and a potential liability:

"What I try to do is understand the person, learn about the person, what he or she likes, what they don't like, what they like doing, their strengths, their weaknesses, and try to get to know them, first and foremost. And gain their trust and give them the support they need, that they can ring me at ten o'clock at night, if they have a question, is it's a personal situation, or they need help, then the door is open... And sometimes I get involved on a personal basis in really not keeping that divide between what's business and what's personal. Sometimes it works; sometimes it's very good because it makes them come to me with any problems. But then sometimes is backfires because they overstep the mark. The trust factor is a two way thing". 


\section{Discussion and Conclusions}

The analysis presented in this paper confirms the value of social capital in international entrepreneurship. It can provide information, interpretation, market opportunities, and some degree of protection against the risks associated with foreignness, newness and smallness. The research also confirms the vital importance of personal trust in sustaining social capital among small firms.

Almost three-quarters of the SMEs stressed the importance of networking in order to penetrate the Brazilian market. Indeed, many took this to be a usual requirement for smaller firms which cannot afford expensive product promotion and which normally focus on niche market segments where they compete on the basis of a company reputation that is often that of their founders or a small number of key individuals within the organization. As noted, SMEs often have the considerable advantage that they are personalized in the eyes of customers or agents whose contact is directly with their owners and/or senior managers.

When SMEs relate directly with agents or partners in a foreign environment, these tend to be with other small firms. However, some SMEs engage only indirectly with unfamiliar environments through piggy-backing - supplying a small number of large firms that are established in those markets (Child \& Rodrigues, 2008). Such customers can, through their international scope, introduce SMEs to new markets which they might not otherwise be in a good position to research, and this was the case with Brazil. On the other hand, the danger of this approach is that it locks the SMEs into a highly dependent and therefore potentially risky position.

Our study of British SMEs suggests that the contribution of social capital varies according to the transactional mode of the firm. Three transactional modes were used. The first involved direct transactions with the customer or client. The second was less direct and involved the supply of products and services to Brazil through an agent, a distributor, or a business partner. The third mode was indirect, in which SMEs supplied major international companies which in turn sell in Brazil. The social capital that an SME required embraced different categories of partners in each of the three modes, and was more extensive in the case of the first two. Standardization of the SME's products or services was particularly associated with use of the third mode. This variation suggests that SMEs are likely to seek different forms of social capital according to their transactional modes with foreign markets. Moreover, social capital embraces links to domestic as well as foreign networks. Domestic social capital tends to perform a different function than that in the target foreign market. It is more useful for assessing feasibility, providing contextual information, and sometimes making initial introductions to foreign partners. Foreign social capital assumes value when the SME starts to operate in the foreign environment, assuming that its presence there is not purely at arm's length.

Our findings point to several issues worthy of further investigation. First, they suggest that the expectations held by the investors in social capital deserve closer attention. When the quality and value that internationalizing entrepreneurs perceive social capital to have exceeds their initial expectations, they appear highly motivated to develop it further; both in terms of deepening the relationship and also in terms of using it to extend the scope of their business involvement in the foreign country. When the social capital is mutually appreciated and seen to provide complementary benefits, past returns from that capital achievement appears very likely to be re-invested into extending and enhancing that capital. Insofar as the dynamics of social capital development depend on decisions of the actors concerned, their subjective expectations and evaluations need to be carefully considered. These evaluations and expectations appear to carry an important psychological element. While decisions to initiate and develop the relationships that provide social capital are subject to economic calculations and contingencies, they also appear to depend significantly on a psychological contract and inter-personal affect.

Second, it appears that social capital, especially that linking with foreign networks, is of varying value. It incurs certain acquisition and maintenance costs. These costs arise from the personal commitment that is required, which may tax the resources of an entrepreneur; especially if he or she 
has diversified internationally. Social capital is like other types of asset in that the returns from investing in them may not always be sufficient to justify the costs. In some circumstances, the cost may outweigh the incremental value provided. Moreover, if the mode of social capital involves entering into a high level of dependency, as with 'piggy-backing' on MNCs, the additional risk may also outweigh its value. Social capital is therefore not invariably a net asset. We have suggested that the type of social capital used will vary according to the international transaction mode of the firm. If this is the case, the transactional mode of SMEs is relevant to this cost-benefit balance and should be taken into account in future investigations.

\section{Implications for Policy}

This study generates important implications for policy. The first concerns the usefulness of social capital to firms' and their ability to develop and maintain relationships that can facilitate internationalization. Many firms start relationships which can be useful to accomplish their strategic goals, but are unable to develop and maintain these relationships. Some firms are able to develop social capital on their own while other firms need institutional help, either because they are new exporters or new to markets. Institutions on their turn may have their own difficulties in contributing to internationalizing firms. A reason for that comes from their poor understanding of their customers' business, mainly if the firm operates in a very specialized niche. In such conditions, export facilitators need to be specialized, which entails the provision of detailed services that can be very costly for SMEs.

Another policy implication is the key role that building and maintaining trust plays in nurturing the social capital on which internationalizing SMEs depend. Trust is built upon personal relationships and personal contact. While reliability in meeting transactional commitments can build confidence in the competence of business partners, trust in their goodwill depends on personal identification, even bonding, between the people concerned. People trust those they like, and the more that such liking can be enhanced by personal contact, the more secure the trust is likely to be. This implies that, despite the additional costs involved, small business entrepreneurs would generally be advised to spend time and effort in cultivating personal relationships with their agents or partners abroad. Modern videoconferencing helps, but export-promoting institutions can greatly assist the process. This research suggests that institutions mainly contribute to process initiation, especially in situations in which the firm is new to export and new to the foreign market it intends to access.

Institutions are more fundamental to SMEs from emerging economies, because most entrepreneurs of these SMEs have never travelled abroad and have not had international experience, even at a personal level. Internationalization can be seen as an insurmountable challenge to them (Puthusserry, Rodrigues, \& Child, 2011; Seifert et al., 2011). As these studies point out, many of SMEs from emerging economies only try to access foreign markets occasionally, either to grab an opportunity or because demand is temporarily reduced in their home country. Internationalization is mainly part of an opportunistic behaviour, which may nevertheless affect the commitment of both local and foreign firms. Showing low commitment may be consequential for a firm in the future, as it may gain a reputation for being unreliable.

Artigo recebido em 28.11.2010. Aprovado em 07.10.2011.

\section{References}

Axelsson, B., \& Easton, G. (Eds.). (1992). Industrial networks: a new view of reality. New York: Routledge. 
Baker, W. E. (1990). Market network and corporate behavior. American Journal of Sociology, 96(3), 589-625.

Biggart, N. W., \& Delbridge, R. (2004). Systems of exchange. Academy of Management Review, 29(1), $28-49$.

Boisot, M. (1998). Knowledge assets: securing competitive advantage in information economy. Oxford: Oxford University Press.

Boisot, M., \& Child, J. (1996). From fiefs to clans and network capitalism: explaining China's emerging economic order. Administrative Science Quarterly, 41(4), 600-628. doi: $10.2307 / 2393869$

Bourdieu, P. (1980). Le capital social: notes provisoires. Actes de la Recherche en Sciences Sociale, 31, 2-3.

Bourdieu, P. (1986). Distinction: a social critique of the judgement of taste. London: Routledge.

Buckley, P. J. (1989). Foreign direct investment by small- and medium-sized enterprises: the theoretical background. Small Business Economics, 1(2), 89-100. doi: 10.1007/BF00398627

Burt, R. S. (1997). The contingent value of social capital. Administrative Science Quarterly, 42(2), 339-365. doi: 10.2307/2393923

Child, J., \& Rodrigues, S. B. (2003). Corporate governance in international joint ventures: toward a theory of partner preferences. In A. Grandori (Ed.), Corporate governance and firm organization (pp. 89-102). Oxford: Oxford University Press.

Child J., \& Rodrigues, S. B. (2008). The process of SME internationalization: British firms entering Brazil. Economia e Gestão, 17(3), 31-55.

Child, J., Rodrigues, S. B., \& Frynas, J. G. (2009). Psychic distance, its impact and coping modes: interpretations of SME decision makers. Management International Review, 49(2), 199-224. doi: 10.1007/s11575-008-0136-3

Coleman, J. S. (1988). Social capital in the creation of human capital [Edição Especial]. American Journal of Sociology, 94, 95-120. doi: 10.1086/228943

Coleman, J. S. (1991). Prologue: constructed social organization. In P. Bourdieu \& J. S. Coleman (Eds.), Social theory for a changing society (pp. 1-14). Boulder, CO: Westview Press.

Freeman, J. (1999). Venture capital as an economy of time. In R. T. A. J. Leenders \& S. M. Gabbay (Eds.), Corporate Social Capital and Liability (pp. 460-479). Norwell, MA: Kluwer Academic Publisher.

Ferrary, M. \& Granovetter, M. (2009). The role of venture capital firms in Silicon Valley's complex innovation network. Economy and Society, 38(2), 326-359. doi: 10.1080/03085140902786827

Fujita, M. (1998). The transnational activities of small and medium sized enterprises. Boston: Kluwer.

Granovetter, M., \& Swedberg, R. (1992). The sociology of economic life. Boulder, CO: Westview Press.

Harris, R. I. D., \& Li, Q. C. (2005). Review of the literature: the role of international trade and investment in business growth and development (Report for UK Trade and Investment). UKTI, London. 
Harris, S., \& Wheeler, C. (2005). Entrepreneurs' relationships for internationalization: functions, origins and strategies. International Business Review, 14(2), 187-207. doi: 10.1016/j.ibusrev.2004.04.008

Johanson, J., \& Mattsson, L. G. (1988). Internationalization in industrial systems: a network approach. In N. Hood \& J. E. Vahlne (Eds.), Strategies in global competition (pp. 287-314). New York: Croom Helm.

Johanson, J., \& Vahlne, J. E. (2003). Business relationship learning and commitment in the internationalization process. Journal International Entrepreneurship, 1(1), 83-101. doi: 10.1023/A:1023219207042

Lu, J. W., \& Beamish, P. W. (2001). The internationalization and performance of SMEs. Strategic Management Journal, 22(6-7), 565-586. doi: 10.1002/smj.184

Nahapiet, J., \& Ghoshal, S. (1998). Social capital, intellectual capital, and the organizational advantage. Academy of Management Review, 23(2), 242-266.

Oviatt, B., \& McDougall, P. (2005). Toward a theory of international new ventures. Journal of International Business Studies, 36(1), 29-41. doi: 10.1057/palgrave.jibs.8400128

Puthusserry, P., Child, J., \& Rodrigues S. B. (2011, setembro). Psychic distance, its business impact and modes of coping through external support: a study of internationalizing British and Indian partner SMEs. Anais do Encontro Nacional da Associação Nacional de Pós-Graduação e Pesquisa em Administração, Rio de Janeiro, RJ, Brasil, 35.

Putnam, R. D. (1993). Making democracy work: civic traditions in modern Italy. Princeton, NJ: Princeton University Press.

Seifert, R., Child, J., \& Rodrigues, S. B. (2011, setembro). The role of interpretation in the internationalization of smaller Brazilian firms. Anais do Encontro Nacional da Associação Nacional de Pós-Graduação e Pesquisa em Administração, Rio de Janeiro, RJ, Brasil, 34.

Stuart, T. E. (1999). Technological prestige and the accumulation of alliance capital. In R. T. A. J. Leenders \& S. M. Gabbay (Eds.), Corporate social capital and liability (pp. 376-389). Boston: Kluwer Academic Publisher.

Transparency International. (2008). Corruption perceptions index. Recuperado em 10 março, 2010, de http://www.transparency.org/news_room/in_focus/2008

Tsai, W., \& Ghoshal, S. (1998). Social capital and value creation: the role of intrafirm networks. Academy of Management Journal, 41(4), 464-476. doi: 10.2307/257085

Uzzi, B., \& Gillespie, J. J. (1999). Corporate social capital and the cost of financial capital: an embeddedness approach. Norwell, MA: Kluwer Academic Publisher.

World Bank. (2010). Doing business: economy rankings. Recuperado em 10 março, 2010, de http://www.doingbusiness.org/economyrankings 